\title{
TEACHERS' QUALITY OF WORK-LIFE IN THE REGIONS OF LATVIA
}

\author{
Anda Grinfelde ${ }^{1}$, Dr.oec.; Inga Vanaga², PhD student, Mg.sc.soc.; Liga Paula³, Dr.sc.soc. \\ 1, ${ }^{2}$ Latvia University of Life Sciences and Technologies, ${ }^{2}$ University of Latvia, Latvian Trade \\ Union of Education and Science Employees
}

\begin{abstract}
In Latvia, during the COVID-19 pandemic teachers represent one of the professions with a special role in solving the problems caused by the crisis. It is important to provide the highest possible quality of education during the state-of-emergency, despite the increased risks of COVID-19 what teachers face while work in a classroom. The workload of teachers has increased and for many of them working conditions have deteriorated. Multiple factors pose a risk to the quality of work-life in general. The aim of the paper is to find out the teachers' opinions on the factors influencing their quality of work-life, comparing the situation in the regions of Latvia, and to develop proposals for strengthening social dialogue to improve teachers' quality of work-life. In February 2021, the Latvian Trade Union of Education and Science Employees conducted a survey "Teachers' Salaries, Principles of Workload Formation and Risks of Professional Burnout", in which 10077 teachers were surveyed to study various aspects of their quality of work-life. The results revealed differences between regions in the teachers' assessment of their quality of work-life and the factors influencing it. The quality of work-life of teachers has decreased, comparing to the situation a year and five years ago. Significantly that 9 out of 10 respondents did not feel cared for at the national level. The authors conclude that it is crucial to improve the social dialogue between the state institutions, employers and employees in order to increase the quality of teachers' work-life.
\end{abstract}

Key words: teachers, quality of work-life, region, social dialogue.

JEL code: R23, K31

\section{Introduction}

In Latvia, teachers' quality of work-life (QWL) has been one of the central issues on political agenda of the education sector for decades. Every year amendments are made to the regulatory enactments regulating wages, but work is ongoing on improving the pay model for teachers. In order to develop proposals for amendments to the regulatory framework to improve the QWL of teachers, it is necessary to ensure a high-quality social dialogue between the state, the municipalities and the educational institutions. Social dialogue means all types of negotiation, consultation or information-sharing among social partners (representatives from employers' and workers' organizations, with or without the involvement of the government) in order to increases support for and the legitimacy of the policies agreed (Ishikawa J., 2003). Similar definition is provided by the International Labour Organization stating that social dialogue is organized on issues of common interest related to economic and social policy (The Social Dialogue and Tripartism Unit). The aim of the social dialogue is to promote cooperation between the social partners and reach an agreement, thus ensuring social stability and economic development in the country. The quality of social dialogue depends on cultural traditions, historical, economic and political processes in the country (Socialais dialogs).

In Latvia, workload of teachers constitutes more than 40 hours per week what exceeds the norm stated in the legal regulations according to which the norm is between 30 and 40 hours per week for most of the professions. The downside is that teachers work overtime and carry out duties that are not paid for. During the spread of the COVID-19, teachers play a special role in tackling the problems caused by the crisis. It is important to ensure the highest possible quality of the education despite increased health risks caused by the pandemic. There is a trend of even further increase in the workload for teachers leading to reduced QWL in general. The aim of the paper is to find out the teachers' opinions on the factors influencing their

1 Anda.Grinfelde@llu.Iv, +37129265476

2 Inga.Vanaga@lizda.lv, +37125998994

3 Liga.Paula@llu.Iv, +371 26321667 
QWL, comparing the situation in the regions of Latvia, and to develop proposals for strengthening social dialogue to improve teachers' QWL. The following tasks were defined: (1) to describe the theoretical aspects of the QWL and social dialogue in education sector; (2) to study and compare the QWL of teachers in Latvian regions; (3) to define the proposals for improving the quality of teachers' QWL. In Latvia, this study is the first attempt to measure teachers' QWL and to compare it between the regions of the country.

\section{Conceptualization of the Quality of Work Life}

The quality of work-life is a concept describing the broader job-related experience of an individual; however, still relatively unexplored and unexplained. There are different views on core constituents of the QWL. It covers a worker's feelings about every dimension of work including economic rewards and benefits, security, working conditions, organisational and interpersonal relationships and its intrinsic meaning in a person's life (Quality of Work Life). As a process it is value-based aiming to meet goals of enhanced effectiveness of the organisation and improved QWL for the employees (Quality of Work Life: it's ...). According to the literature review done by S. I. D. Ishak, N. A Razak, H. Hussin, N. S. D. Fhiri and A. S. Ishak (2018:4), frequently used variables in teachers' QWL research are job satisfaction, demographic factor, pay and benefits, supervision, organization commitment, growth and development, safety and healthy environment. Other social integration, attitude and perception, employee participation, work life balance and relationship, rewards, team work, welfare and opportunities, autonomy, and other (Ishak S. I. D., Razak N. A., Hussin H., Fhiri N. S. D., Ishak A. S., 2018:4). Recent study in Sweden has shown that teacher job satisfaction is greatly affected by school working conditions, teacher workload, teacher cooperation and student discipline (Toropova A., Myrberg E., Johansson S., 2021:92). P. Andersson and S. Kopsen (2019) have focused on boundary processes between school and working life. Another study has confirmed a close relationship between burnout and job satisfaction, self-efficacy, coping strategies and social support among teachers: respondents with lower burnout scores reported stronger self-efficacy, more frequent using of positive coping strategies, and better workplace social support (Smetackova I., Viktorova I., Pavlas Martanova V., Pachova A., Francova V., Stech S., 2019:6). Authors of the paper, on the basis of theoretical aspects of QWL, indicate factors that influence the teachers' $\mathrm{QWL}$, such as motivation for work, labour rights, the working environment and relations, social guarantees, professional support, social assistance and benefits, reconciliation of work and private life (Table 1). The study focuses on the following aspects of QWL: remuneration, workload, psycho-social working environment, relations with the employer, health insurance and reconciliation of work and private life. 
Factors affecting the teachers' quality of work life

\begin{tabular}{|c|c|c|}
\hline No & Factors & Major objective/ subjective aspects \\
\hline 1 & Motivation to work & Salary, workload, vacation, assessment of teacher work quality \\
\hline 2 & Labour rights & Equal opportunities for all, respect for labour rights \\
\hline 3 & Working environment & $\begin{array}{c}\text { Working conditions, safety at work, psycho-social working } \\
\text { environment }\end{array}$ \\
\hline 4 & Relationships at work & $\begin{array}{l}\text { Relations with the employer, relations with the pupils, relations } \\
\text { with the parents of children }\end{array}$ \\
\hline 5 & Social guarantees/ security & Health insurance, benefits \\
\hline 6 & Professional support & Methodological support, professional development \\
\hline 7 & Social assistance & Social support for pre-retirement age, compensatory allowance \\
\hline 8 & $\begin{array}{l}\text { Reconciliation of work and } \\
\text { private life }\end{array}$ & Flexible working time, care for dependent children or parents \\
\hline
\end{tabular}

\section{Source: authors' compilation based on the literature studies}

Social dialogue is an important process for improving the quality of work life for teachers, since the labour costs and working conditions of teachers are covered by both the national government and municipal budgets. The funding of the education sector is the most important factor influencing the teachers working life and it has been at the centre of political debate for a long time in Latvia. Representativeness of social partners, trade unions and employers' organizations, is crucial in negotiations at different levels (The Social Dialogue and Tripartism Unit), therefore survey results reflecting opinions and attitudes of teachers are extremely supportive in argumentation developed by the teachers' trade union.

\section{Research methodology}

In February 2021, the authors of the paper conducted a survey "Teachers' Salaries, Principles of Workload Formation and Risks of Professional Burnout" on behalf of the Latvian Trade Union of Education and Science Employees (LIZDA), in which 10077 teachers were surveyed to study various aspects of their QWL. The questionnaire was developed and posted on the webpage visidati.lv. Information about the survey was disseminated via LIZDA homepage, trade union's member organizations in schools, and social media. The respondents were offered to use symmetric 5-point Likert scale (strongly agree, slightly agree, neither agree nor disagree, slightly disagree, strongly disagree) in order to assess the statements. The teachers' survey was conducted on the basis of the methodological and ethical principles of the online survey (Roberts D. L., Allen, J. P., 2015; Toepoel V., 2015). The survey was anonymous and the results were used only in an aggregated way. The survey identified the views of respondents on the financial and psycho-emotional well-being of teachers in the workplace in order to raise motivation for teachers to work and reduce risks of professional burnout. Part of the results obtained in the study is presented in the paper describing the self-assessment of teachers' QWL and the factors affecting it. The authors also present comparison the situation in Latvia's regions and compiling proposals on ways of strengthening social dialogue to improve the quality of the life of educators. The research sample $(n=10077)$ included teachers from all regions of Latvia (Figure 1), different age and seniority groups working in one or more (small/medium/large) educational establishments. Among them, there were pre-school teachers (17.5 \%), teachers of general education institutions (54.4\%), teachers of the vocational secondary education institutions $(2.4 \%)$, special education teachers $(3.8 \%)$, interest education teachers $(8.8 \%)$, vocational 
orientation teachers (2.4\%), school principals and administration members (6.4\%), and other pedagogical staff $(4.3 \%)$.

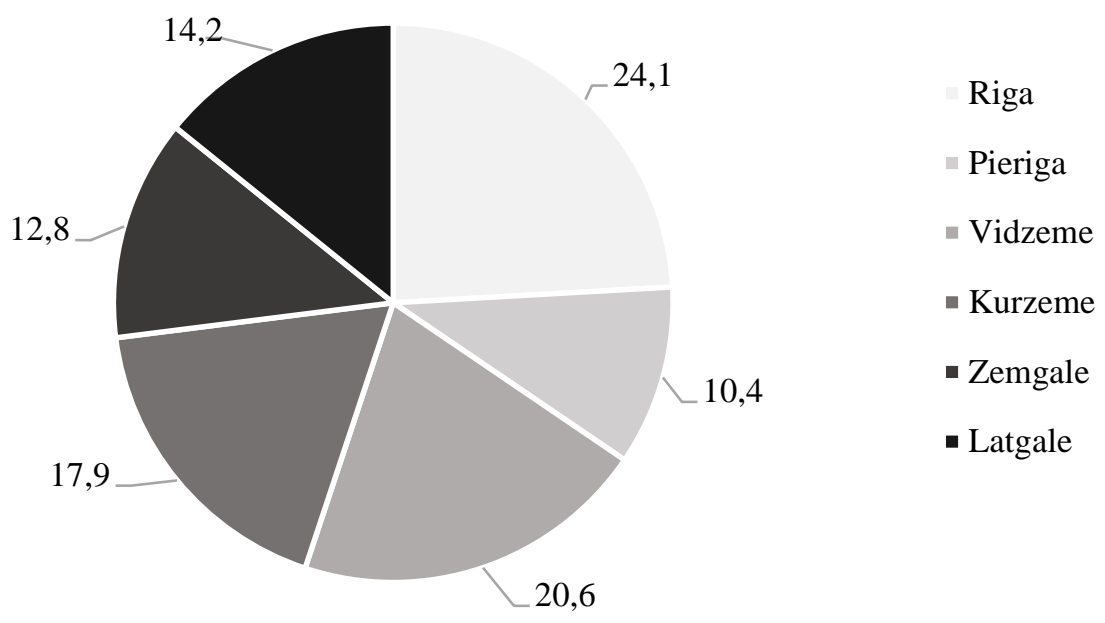

Source: authors' calculations based on LIZDA data, 2021

Fig. 1. The number of respondents representing the statistical regions of Latvia, \%

Pearson Chi-Square tests for categorical variables were performed to assess the statistical significance of possible differences between respondents from different regions in Latvia. For all analyses, a $p$-value of $<0.01$ (two-tailed) was considered statistically significant. The analyses were performed in SPSS.

\section{Regional disparities: analysis of the research results}

One of the most important factors influencing the teachers' QWL is the motivation for work in order to provide the pupils with the highest possible quality of the educational service. On average, only $19 \%$ of the respondents in Latvia believed that they have received the appropriate remuneration for their job. According to the Pearson Chi-Square test, no statistically significant difference was detected among the respondents from different regions regarding this aspect. Still, according to the survey data (Figure 2), the biggest difference is between those Pieriga teachers (25\%) and Vidzeme teachers (17\%) who more frequently have pointed that they slightly agreed or strongly agreed with the statement (answers "slightly agree" and "strongly agree" are counted together in Figure 2). 


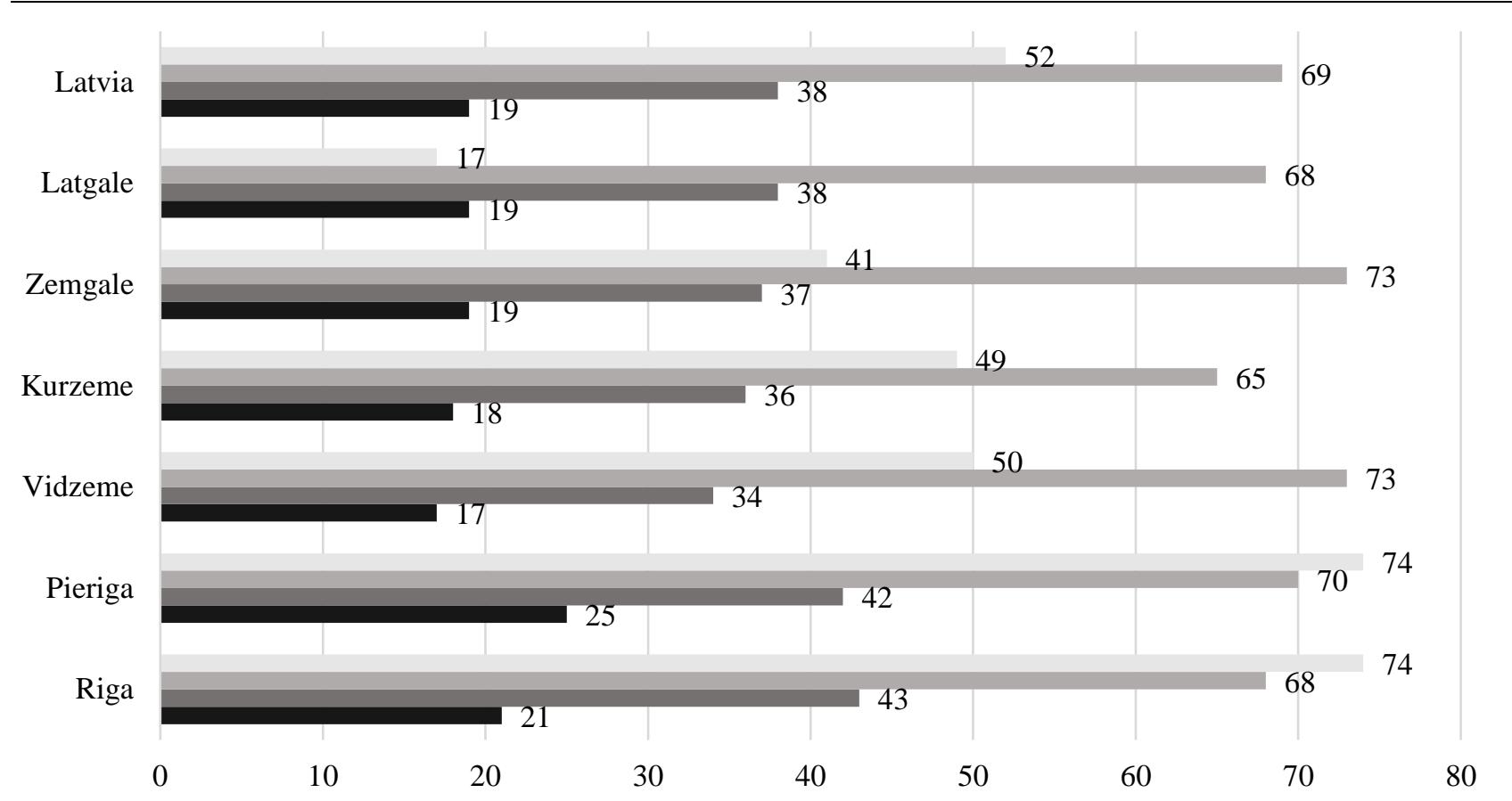

I have health insurance as an additional bonus for my work in an educational institution

I feel stressed at work because I am afraid to get sick of COVID-19

I am satisfied with the quality bonus arrangements at my educational institution

I receive a remuneration appropriate to my pedagogical work

Source: authors' calculations based on LIZDA data, 2021

\section{Fig. 2. Respondents' views on the statements about job motivation} and health insurance, \%

The quality of the teacher's work is stimulated by setting a quality premium. In recent years, however, the arrangements for the granting of premiums were changed and the study therefore measured how satisfied the teachers were with the quality arrangements in their schools. Statistically significance difference is between the respondents from Riga (43\%), Pieriga (42\%) and Vidzeme region (34 \%) and their satisfaction about the quality premium arrangements $(p<0.01)$. In teachers' attitudes towards the risk of getting COVID-19, there were no statistically significant differences identified between regions. However, teachers from Vidzeme (73\%) and Zemgale (73\%) in comparison to Kurzeme region (65 \%) more frequently reported on stress caused by their fear of getting sick with COVID-19. Teachers admitted that employer-paid health insurance ensures some security. There is a correlation between variables such as a region and the possibility to have a health insurance $(p<0,01)$ : seven out of ten teachers in Riga (74 \%) and Pieriga (74\%) indicated that they had access to health insurance what they treated as an additional bonus, while in Latgale only two teachers out of ten or $17 \%$ admitted this opportunity.

The study also clarified the views of teachers on the statements related to relationships at work and the performance of their duties (Figure 3 ). 


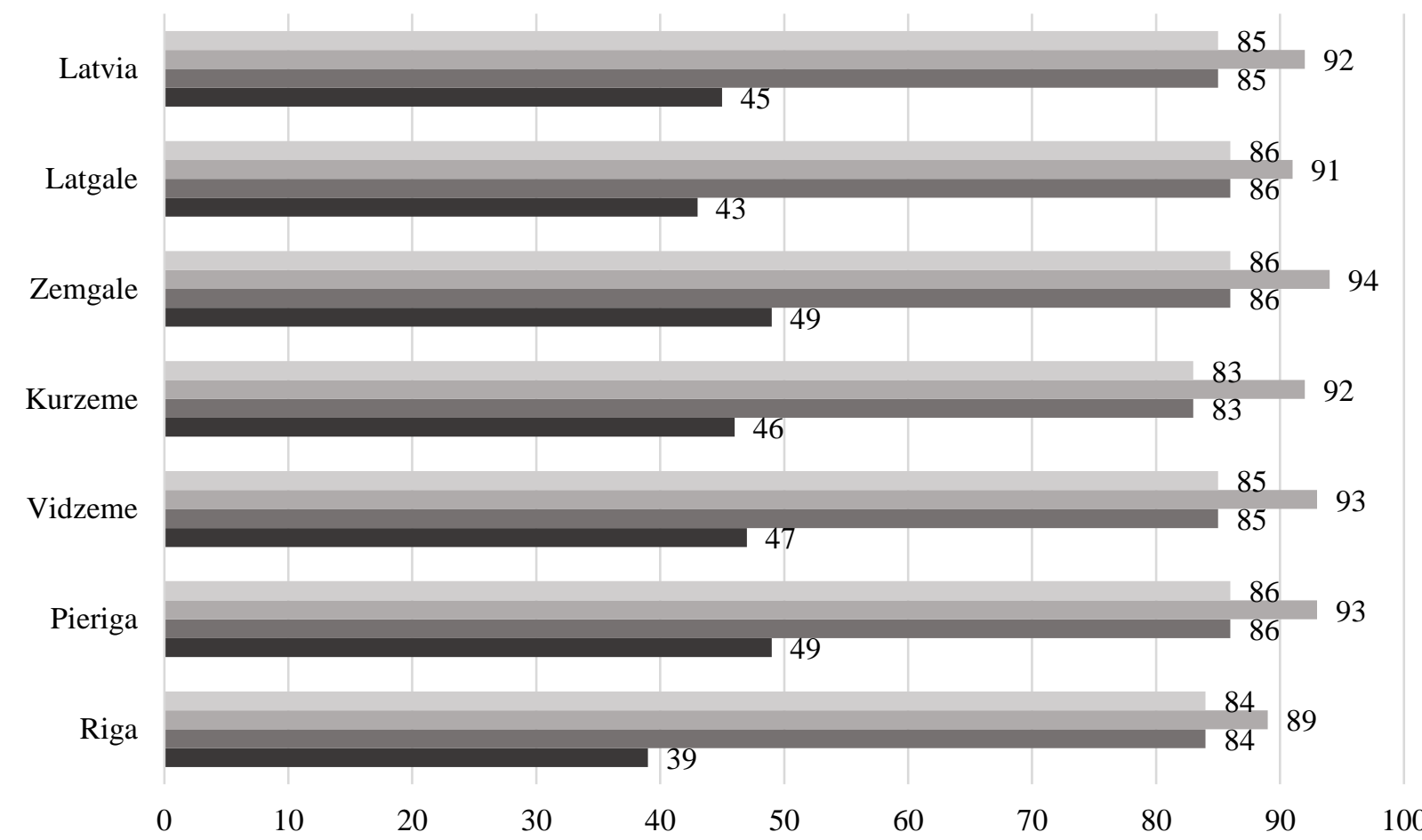

It is becoming increasingly difficult for teachers to combine responsibilities at work with family responsibilities

Teachers are increasingly complaining that more time is needed to complete all their job responsibilities

Teachers need to work more often with colleagues who are experiencing emotional stress

- Teachers increasingly have problems in communication with the administration

\section{Source: authors' calculations based on LIZDA data, 2021}

Fig. 3. Opinion of the respondents on the relationships at work and the performance of their duties

Teachers in Pieriga (49\%) and Zemgale (49\%) more often than those in Riga (39\%) indicated that they have increasingly faced problems with the administration. Equally in all regions, around $85 \%$ of educators strongly agreed or slightly agreed that more collaboration is required with colleagues experiencing emotional tension. There is a statistically significant relationship between variables such as a region and growing problems in communication with the administration $(p<0.01)$, and a region and collaboration with colleagues experiencing emotional tension $(p<0.01)$. Similarly, there is a statistically significant relationship $(p<0.01)$ between variables such as a region and the fact that teachers are frustrated by the need to take more and more time to complete all job responsibilities. In Riga region, the ratings are slightly more positive ( $89 \%$ ) compared to the Zemgale region (94\%), but on average every 9 out of 10 teachers responded positively.

One of the key factors influencing working life is the possibilities for reconciliation work and private life. The survey revealed that on average teachers' working hours have actually increased during the COVID-19 pandemic by an average of 11 hours per week due to an increase in the amount of additional duties to be performed. The increase includes also additional time for lesson preparation because remote teaching requires different approach, learning materials and home tasks, more active cooperation and communication with parents and pupils. According to the survey, the actual working time of the respondents, on average, is 49 hours a week. It should be noted that these additional hours are neither listed nor paid. This suggests that the personal lives and interests of teachers are at odds with their working lives, which are essential aspects of quality of life. In general, quality of life describes all areas of life, but the need to balance with work and other aspects of life is essential. In all regions, teachers in similar ways 
(around $85 \%$ ) find it increasingly difficult to connect family responsibilities with their job, but there was no, however, statistically significant differences detected.

Within the study, the teachers were asked to assess their QWL according to a 10-point scale (1 meant the lowest and 10 meant the highest assessment). The respondents were asked to compare their QWL five years ago, a year ago and now during the COVID-19 pandemic. The overall assessment of the QWL and its regional comparison is presented in Figure 4.

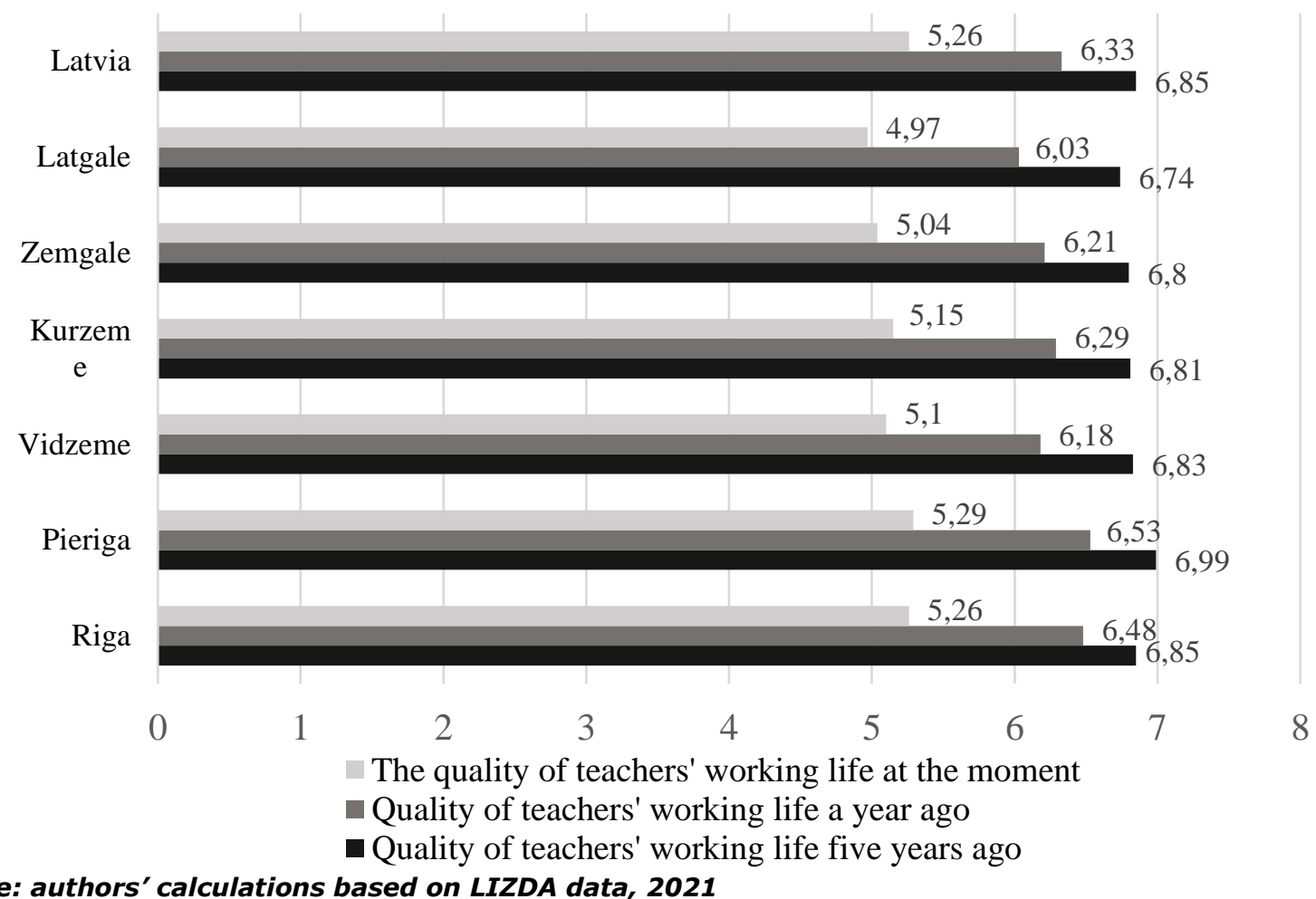

Source: authors' calculations based on LIZDA data, 2021

Fig. 4. Respondents opinions on their quality of work life, 10-point scale.

For all three QWL measurements, there is a statistically significant difference between regions $(p<0.01)$. On average, in Latvia, teachers estimate their QWL five years ago by 0.52 points lower than a year ago and by 1.07 points lower than in 2021 during the pandemic. Compared to Latvian average (1.59), the teachers in Zemgale believed that their QWL has declined by 1.76 points during the last five years; the respondents from Latgale were of similar opinion (1.77 points).

Ensuring the teachers' QWL is a joint responsibility of educational institutions, municipalities and organizations at national level. Representatives of all these levels are social dialogue partners which should mutually agree on areas of responsibility, so that teachers' work is evaluated. The study identified whether teachers feel support and care from their schools, municipalities and the state (Figure 5). On average, $70 \%$ of educators across Latvia and similar in all regions strongly agree and slightly agree that they are cared of at the level of the educational institution. There is a similar consensus between regions on the state support for educators, but on average only $12 \%$ of the respondents agree with this statement. However, there was no statistically significant relationship between variables such as a region and support (care) at the level of the educational establishment and at the national level. Statistically significant relationship ( $p<0.01)$, however, was indicated between respondents' regional affiliation and municipal support: there were differences between Pieriga, in which half of the teachers (52 \%) admitted municipal support in comparison to Kurzeme region (33\%) and Latgale region (31\%) where only one-third of the teachers was positive. 


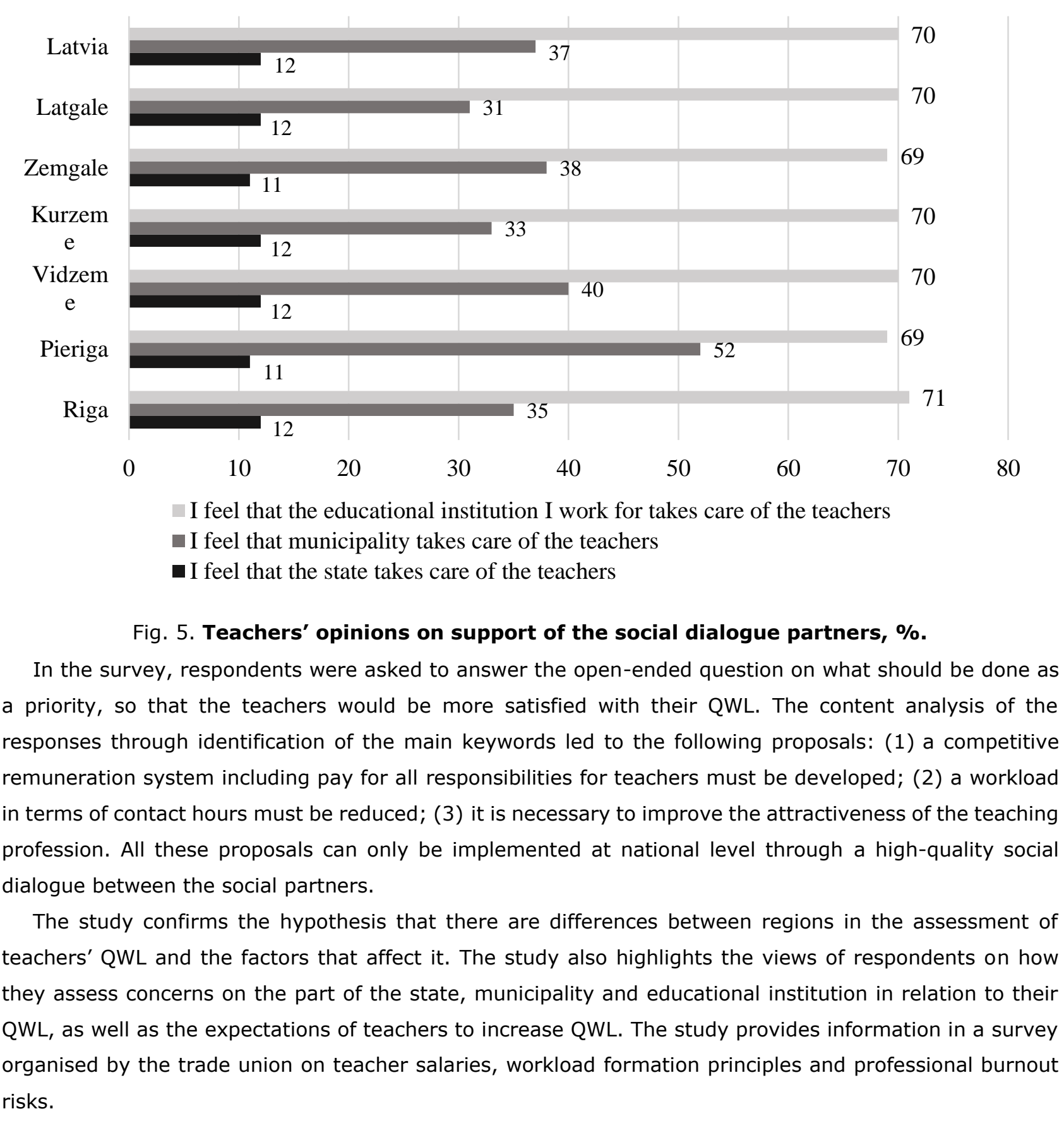

\section{Conclusions and recommendations}

1) There are differences in opinions between the respondents from different Latvia's regions in the assessment of the teachers' QWL and the factors affecting it. In Riga, the teachers are more positive whereas in Latgale and Zemgale the respondents are more critical. Overall, the teachers' QWL in all regions of Latvia has decreased compared to the situation a year ago and five years ago, with a slightly more rapid decrease observed in Latgale and Zemgale regions.

2) In general, assessment of the aspects of QWL related to the motivation for work was critically low; while in Riga and Pierga they were somewhat less critically assessed, respondents from Vidzeme region were the most critical in terms of motivation for work.

3) A very different situation is regarding the availability of employer-paid health insurance: two-thirds of the teachers in Riga and Pierga regions can use it, half of the respondents in Vidzeme and Kurzeme 
also, whereas only 4 out of 10 respondents in Zemgale and 2 out of 10 teachers in Latgale have employer-paid health insurance.

4) In Vidzeme and Zemgale, in contrast to Kurzeme, teachers are more often stressed at work because they are afraid of getting sick with COVID-19.

5) In Riga, teachers admitted that they have increasingly faced problems in communication with administration whereas in Zemgale region teacher more struggle with time constrains indicating that they needed more time to complete all job responsibilities.

6) Teachers believe that in order to improve their QWL, competitive teacher remuneration system including pay for all the duties performed must be defined as a priority; reduced number of contact hours and increased prestige of the teaching profession were also mentioned as crucial factors.

7) Half of the teachers from Pieriga indicated that they feel municipal support, unlike, Latgale, where only a third of the respondents were positive about municipal support. Policy makers need to develop social dialogue at national level, since only 1 out of 10 teachers feel support and care at national level, while 7 out of 10 assessed highly support at the level of the educational establishment. In Latvia, the social dialogue between the social partners represented by the state and employers should be improved to improve the quality of life and the prestige of the teaching profession.

\section{Bibliography}

1. Andersson, P., Kopsen, S. (2019). VET Teachers Between School and Working Life: Boundary Processes Enabling Continuing Professional Development. Journal of Education and Work, Volume 32, Issues 6-7, pp. 537551. DOI: $10.1080 / 13639080.2019 .1673888$

2. Ishak, S.I.D., Razak, N.A., Hussin, H., Fhiri, N.S.D., Ishak A.S. (2018). A Literature Review on Quality Teacher's Working Life. MATEC Web of Conferences, Volume 150, Issue 1:05094 Retrieved: DOI: 10.1051/matecconf/201815005094 Access 02.04.2021.

3. Ishikawa, J. (2003). Key Features of National Social Dialogue: A Social Dialogue Resource Book. Geneva: International Labour Office, $52 \mathrm{p}$. Retrieved: file://C:/Users/User/AppData/Local/Temp/resource_book_key_features.pdf Access 18.03.2021.

4. Quality of Work Life. Retrieved: https://www.economicsdiscussion.net/human-resource-management/qualityof-work-life/quality-of-work-life/32426 Access 18.03.2021.

5. Quality of Work Life: it's Meaning and Definition. Employee Management. Retrieved: https://www.yourarticlelibrary.com/employee-management/quality-of-work-life-its-meaning-and-definitionemployee-management/26112 Access 18.03.2021.

6. Roberts, D. L., Allen, J. P. (2015). Exploring Ethical Issues Associated with Using Online Surveys in Educational Research. Educational Research and Evaluation, Volume 21, Issue 2, pp. 95-108. DOI: 10.1080/13803611.2015.1024421

7. Smetackova, I., Viktorova, I., Pavlas Martanova, V., Pachova, A., Francova, V., Stech, S. (2019). Teachers Between Job Satisfaction and Burnout Syndrome: What Makes Difference in Czech Elementary Schools. Frontiers in Psychology, 10:2287. DOI: 10.3389/fpsyg.2019.02287

8. Socialais dialogs (Social dialogue). Retrieved: https://arodbiedribas.Iv/socialais-dialogs/ Access 18.03.2021.

9. Social Dialogue and Tripartism Unit (DIALOGUE). Retrieved: https://www.ilo.org/global/about-the-ilo/how-theilo-works/departments-and-offices/governance/dialogue/lang--en/index.htm Access 02.04.2021.

10. Toepoel, V. (2015). Doing Surveys Online. London: Sage Publications, 280 p.

11. Toropova, A., Myrberg, E., Johansson, S. (2021). Teacher Job Satisfaction: The Importance of School Working Conditions and Teacher Characteristics. Educational Review, Volume 73, Issue 1, pp. 71-97. DOI: 10.1080/00131911.2019.1705247 